\title{
Liver X Receptor Agonist Therapy Prevents Diffuse Alveolar Hemorrhage in Murine Lupus by Repolarizing Macrophages
}

\author{
Shuhong Han ${ }^{1}$, Haoyang Zhuang ${ }^{1}$, Stepan Shumyak ${ }^{1}$, Jingfan $\mathrm{Wu}^{1}$, Chao Xie ${ }^{2}$, Hui $\mathrm{Li}^{2}$, \\ Li-Jun Yang ${ }^{2}$ and Westley H. Reeves ${ }^{1 *}$ \\ 'Division of Rheumatology \& Clinical Immunology, Department of Medicine, University of Florida, Gainesville, FL, \\ United States, ${ }^{2}$ Department of Pathology, Immunology, and Laboratory Medicine, University of Florida, Gainesville, FL, \\ United States
}

OPEN ACCESS

Edited by:

George C. Tsokos, Harvard Medical School,

United States

Reviewed by:

Nagaja Capitani,

University of Siena, Italy

Caroline Jefferies,

Cedars-Sinai Medical Center,

United States

*Correspondence: Westley H. Reeves

whreeves@ufl.edu

Specialty section: This article was submitted to Inflammation,

a section of the journal

Frontiers in Immunology

Received: 20 September 2017

Accepted: 16 January 2018

Published: 02 February 2018

Citation:

Han S, Zhuang H, Shumyak S, Wu J, Xie $C, L i H$, Yang $L-J$ and Reeves WH (2018) Liver X Receptor Agonist

Therapy Prevents Diffuse Alveolar Hemorrhage in Murine Lupus by Repolarizing Macrophages. Front. Immunol. 9:135. doi: 10.3389/fimmu.2018.00135
The generation of $\mathrm{CD}_{138^{+}}$phagocytic macrophages with an alternative (M2) phenotype that clear apoptotic cells from tissues is defective in lupus. Liver $\mathrm{X}$ receptor-alpha $(L X R \alpha)$ is an oxysterol-regulated transcription factor that promotes reverse cholesterol transport and alternative (M2) macrophage activation. Conversely, hypoxia-inducible factor 1- $\alpha$ (HIF1 $\alpha)$ promotes classical (M1) macrophage activation. The objective of this study was to see if lupus can be treated by enhancing the generation of M2-like macrophages using LXR agonists. Peritoneal macrophages from pristane-treated mice had an M1 phenotype, high HIF $\alpha$-regulated phosphofructokinase and TNF $\alpha$ expression (quantitative PCR, flow cytometry), and low expression of the LXR $\alpha$-regulated gene ATP binding cassette subfamily A member 1 (Abca1) and /110 vs. mice treated with mineral oil, a control inflammatory oil that does not cause lupus. Glycolytic metabolism (extracellular flux assays) and Hif1a expression were higher in pristane-treated mice (M1-like) whereas oxidative metabolism and LXR $\alpha$ expression were higher in mineral oiltreated mice (M2-like). Similarly, lupus patients' monocytes exhibited low LXR $\alpha / A B C A 1$ and high HIF1 $\alpha$ vs. controls. The LXR agonist T0901317 inhibited type I interferon and increased ABCA1 in lupus patients' monocytes and in murine peritoneal macrophages. In vivo, T0901317 induced M2-like macrophage polarization and protected mice from diffuse alveolar hemorrhage (DAH), an often fatal complication of lupus. We conclude that end-organ damage (DAH) in murine lupus can be prevented using an LXR agonist to correct a macrophage differentiation abnormality characteristic of lupus. LXR agonists also decrease inflammatory cytokine production by human lupus monocytes, suggesting that these agents may be have a role in the pharmacotherapy of lupus.

Keywords: lupus, diffuse alveolar hemorrhage, therapy, inflammation, macrophage polarization, liver $\mathrm{X}$ receptors, hypoxia-inducible factor $1-\alpha$

\section{INTRODUCTION}

Mice with pristane-induced lupus develop an autoimmune syndrome closely resembling systemic lupus erythematosus (SLE) with lupus-specific autoantibodies, nephritis, arthritis, diffuse alveolar hemorrhage (DAH), and hematological manifestations (1). Pristane-induced lupus in C57BL/6 (B6) mice is the only model of lupus-associated DAH $(2,3)$, an often fatal complication seen in $~ 3 \%$ of SLE patients (4). DAH in pristane-induced lupus is associated with antineutrophil cytoplasmic antibody negative pulmonary capillaritis and is mediated by macrophages $(\mathrm{M} \phi)(3)$. 
Pristane-treated mice develop lupus in the setting of nonresolving inflammation (5), which may result in part from impaired clearance of dead cells (6). CD11b+F4/80 ${ }^{+} \mathrm{Ly}^{+} \mathrm{C}^{\mathrm{hi}}$ inflammatory $\mathrm{M} \phi\left(\mathrm{Ly}_{6} \mathrm{C}^{\text {hi }} \mathrm{M} \phi\right)$ accumulate in the peritoneum after pristane injection $(6,7)$. In contrast, peritoneal exudate cells (PEC) from mice treated with mineral oil (MO), an inflammatory hydrocarbon that does not cause lupus, are progressively enriched in a subset of anti-inflammatory $\mathrm{CD} 11 \mathrm{~b}^{+} \mathrm{F} 4 / 80^{+} \mathrm{CD} 138^{+} \mathrm{M} \phi$ reminiscent of alternatively activated (M2) M (6). CD138+ $\mathrm{M} \phi$ are highly phagocytic for apoptotic cells and their deficiency in pristane-treated mice may promote non-resolving inflammation resulting in end-organ damage.

Although an over-simplification $(8,9)$, bone marrow (BM)derived $\mathrm{M} \phi$ are classified as classically activated (M1) or alternatively activated (M2). Murine M1 M $\phi$ express high levels of Ly6C, CD80/CD86, CD274 (PD-L1), and CCR2 and produce TNF $\alpha$, IL-1 $\beta$, and IL-12. In contrast, M2 M $\phi$ express Fizz1 (Retnlb), Ym1 (Chil3), Arginase 1 (Arg1), CD206 (Mrc1), CD273 (PD-L2, Pdcd1lg2), scavenger receptors, $\mathrm{CX}_{3} \mathrm{CR}$, and low levels of Ly6C and produce TGF $\beta$ and IL-10 (10). Phosphorylation of the transcription factor CREB promotes M2 M $\phi$ polarization (11). $\mathrm{CD} 138^{+} \mathrm{M} \phi$ from MO-treated mice express M2 activation markers and have high levels of p-CREB (6). The present study addresses the role of two additional transcription factors, liver $\mathrm{X}$ receptor-alpha $(\mathrm{LXR} \alpha)$ and hypoxia inducible factor 1-alpha (HIF1 $\alpha$ ), in lupus.

Liver X receptor-alpha, an oxysterol-regulated transcription factor activated via the endosome/lysosome associated Lamtor1mTORC1 pathway, helps determine whether or not M0 M $\phi$ polarize to M2 $(12,13)$. Oxysterols derived from the phagocytosis of apoptotic cells activate the LXR pathway in M $\phi$, upregulating genes involved in the recognition of dead cells (Mertk) and cholesterol efflux (e.g., ATP binding cassette A1, Abca1) and downregulating proinflammatory gene expression (14). Along with their dependence on LXR $\alpha, M 2 \mathrm{M} \phi$ rely on oxidative phosphorylation and fatty acid oxidation to fuel mitochondrial oxidative metabolism whereas M1 M $\phi$ rely on glycolysis $(15,16)$. M1 polarization is promoted by $\operatorname{HIF} 1 \alpha$, a key regulator of glycolytic metabolism $(15,17,18)$, which upregulates glycolytic enzymes, proinflammatory cytokines, and expression of the M1 marker CD274 (17). We show that an imbalance between LXR $\alpha$ and HIF $1 \alpha$ activity is involved in the pathogenesis of end-organ damage (DAH) in lupus. Therapy with an LXR agonist corrected this imbalance and prevented DAH.

\section{MATERIALS AND METHODS}

\section{Mice}

B6 mice (Jackson) maintained under specific pathogen free conditions were injected with pristane (Sigma-Aldrich, $0.5 \mathrm{ml}$ i.p.), mineral oil (MO; C.B. Fleet Co.), PBS, or left untreated. PEC were collected 14 days later. Some mice were treated with pristane on d0 plus either LXR agonist T0901317 (200 $\mu$ g in DMSO per mouse i.p. daily) or DMSO alone. Mice received T0901317 on d1-d14 or on $\mathrm{d} 1-\mathrm{d} 3, \mathrm{~d} 3-\mathrm{d} 14$, or $\mathrm{d} 7-\mathrm{d} 14$ only. On d14, lungs were evaluated for DAH by gross inspection of the excised lungs followed by microscopic confirmation as described previously (3). This study was carried out in accordance with the recommendations of the Animal Welfare Act and US Government Principles for the Utilization and Care of Vertebrate Animals and was approved by the UF IACUC.

\section{Patients and Healthy Donors}

For flow cytometry and isolation of peripheral blood mononuclear cells (PBMCs), heparinized blood was obtained from 22 SLE patients meeting ACR criteria who were seen consecutively in the UF Autoimmune Disease Clinic (19) and 24 matched healthy donors with no autoimmune disease. For RNA isolation, blood was collected in PAXgene tubes (BD Biosciences). SLE activity was assessed using the SLEDAI (20). This study was carried out in accordance with the recommendations of the International Committee of Medical Journal Editors and was approved by the UF IRB. All subjects gave written informed consent in accordance with the Declaration of Helsinki.

\section{Quantitative PCR}

Quantitative PCR (Q-PCR) was performed as described (21) using RNA extracted from $10^{6}$ mouse PEC (TRIzol, Invitrogen). RNA was isolated from human blood with the QIAamp RNA Blood Mini Kit (Qiagen). cDNA was synthesized using the Superscript II First-Strand Synthesis kit (Invitrogen). SYBR Green Q-PCR analysis was performed using an Opticon II thermocycler (Bio-Rad). Gene expression was normalized to $18 \mathrm{~S}$ RNA, and the expression level was calculated using the $2^{-\Delta \Delta \mathrm{Ct}}$ method. Primer sequences are in Table 1.

\section{Culture of Adherent Peripheral PBMC- Derived Monocytes}

Peripheral blood mononuclear cells from lupus patients and healthy donors were isolated from heparinized blood by density gradient centrifugation (Ficoll-Hypaque, GE Healthcare BioSciences). PBMCs were incubated at $37^{\circ} \mathrm{C}$ for $1 \mathrm{~h}$ in AIM-V medium (Invitrogen), and non-adherent cells were removed. Adherent cells (90-95\% CD14+) were lysed with RLT lysis buffer (Qiagen) for RNA isolation. Monocytes were cultured with LXR $\alpha$ agonist GW3965 (1 $\mu \mathrm{M}$, Sigma-Aldrich), for $24 \mathrm{~h}$ in AIM-V medium before isolating RNA. Gene expression was measured by Q-PCR. In some experiments, monocytes were treated with IFN $\alpha(1,000 \mathrm{U} / \mathrm{ml})(\mathrm{R} \& \mathrm{D}$ Systems) for $1 \mathrm{~h}$, followed by addition of LXR agonists (GW3965 or T0901317, $1 \mu \mathrm{M}$ in DMSO), or DMSO alone, and then cultured for $24 \mathrm{~h}$. Some cells were lysed for RNA isolation. The remaining cells were analyzed by flow cytometry. About 10-50,000 events per sample were acquired using an LSRII flow cytometer (BD-Biosciences) and analyzed with Flowjo software (Tree Star Inc.).

\section{Flow Cytometry and Sorting of Mouse Mф}

Flow cytometry was performed as described (21) using antimouse CD16/32 (Fc Block; BD Biosciences) before staining with primary antibody or isotype controls. Cells were surface-stained, then fixed/permeabilized (Fix-Perm buffer, eBioscience) before intracellular staining. Antibodies are listed in Table 2. Uptake of low-density lipoproteins was assessed by incubating PEC 
TABLE 1 | Primer sequences.

\begin{tabular}{|c|c|c|}
\hline Gene & Forward primer $\left(5^{\prime} \rightarrow 3^{\prime}\right)$ & Reverse primer $\left(5^{\prime} \rightarrow 3^{\prime}\right)$ \\
\hline $18 \mathrm{~S}$ & AGGCTACCACATCCAAGGAA & GCTGGAATTACCGCGGCT \\
\hline \multicolumn{3}{|c|}{ Human } \\
\hline $\begin{array}{l}\text { NR1H3 } \\
(L X R \alpha)\end{array}$ & ACTCGAAGATGGGGTTGATG & GGAGGTACAACCCTGGGAGT \\
\hline$A B C A 1$ & AACAAGCCATGTTCCCTCAG & GACGCAAACACAAAAGTGGA \\
\hline MX1 & CACGAGAGGCAGCGGGATCG & ССТTGССTСTССАСТTАTСТTС \\
\hline LYGE & AGGCTGCTTGGTTGTGAC & AGCAGGAGAAGCACATCAGC \\
\hline HIF1A & TCCATGTGACCATGAGGAAA & TCTTCCTCGGCTAGTTAGGG \\
\hline PFKL & СTCCTCGCCCACCAGAAG & CTGTGTGTCCATGGGAGATG \\
\hline HK2 & TCTATGCCATCCCTGAGGAC & AAACCCAGTGGGAGCTTCTT \\
\hline \multicolumn{3}{|l|}{ Mouse } \\
\hline Nr1h3 & TGGAGAACTCAAAGATGGGG & TGAGAGCATCACCTTCCTCA \\
\hline Abca1 & GCTGCAGGAATCCAGAGAAT & CATGCACAAGGTCCTGAGAA \\
\hline Hif1a & TCCATGTGACCATGAGGAAA & GGCTTGTTAGGGTGCACTTC \\
\hline$M \times 1$ & GATCCGACTTCACTTCCAGATGG & CATCTCAGTGGTAGTCCAACCC \\
\hline $1 / 10$ & GGTTGCCAAGCCTTATCGGA & АССТGCTCСАСТGССТTGCT \\
\hline Tnfa & $\begin{array}{l}\text { CATCTTCTCAAAAT } \\
\text { TCGAGTGACAA }\end{array}$ & $\begin{array}{l}\text { TGGGAGTAGAC } \\
\text { AAGGTACAACCC }\end{array}$ \\
\hline Chil3 & TGTACCAGCTGGGAAGAAAC & GAGAGCAAGAAACAAGCATGG \\
\hline G6pd & CCCCCACAGTCTATGAAGCA & TGGTTCGACAGTTGATTGGA \\
\hline Pfkl & GGGCTGATTGGCTATTCATT & TGATGATGTTCAGCCGAGAG \\
\hline Hk2 & GGGTTCACCTTCTCCTTCC & TTCAGCAAGGTGACCACATC \\
\hline
\end{tabular}

TABLE 2 | Antibodies used for flow cytometry.

\begin{tabular}{|c|c|c|}
\hline Specificity (clone) & Fluorochrome & Source \\
\hline Mouse CD273 (TY25) & Phycoerythrin & Biolegend \\
\hline Mouse CDE274 (10F.9G2) & Phycoerythrin & Biolegend \\
\hline Mouse CD138 (281-2) & $\begin{array}{l}\text { Phycoerythrin; } \\
\text { Allophycocyanin }\end{array}$ & Biolegend \\
\hline Mouse CD11b (M1/70) & Brilliant violet-421 & Biolegend \\
\hline Mouse Ly6C (HK1.4) & Allophycocyanin-Cy7 & Biolegend \\
\hline Mouse Ly6G (1A8) & Phycoerythrin & BD Bioscience \\
\hline Mouse CD80 (16-10A1) & PerCP-Cy5.5 & Biolegend \\
\hline Mouse CD86 (GL-1) & Allophycocyanin-Cy7 & Biolegend \\
\hline Mouse CD36 (HM36) & Phycoerythrin & Biolegend \\
\hline Mouse TNF $\alpha$ (MP6-XT22)* & Allophycocyanin & Biolegend \\
\hline $\begin{array}{l}\text { Mouse/human ABCA1 } \\
(5 \mathrm{~A} 1-1422.22)^{\mathrm{a}}\end{array}$ & Allophycocyanin & Novus Biologicals \\
\hline Human CD14 (MфP9) & PerCP & BD Bioscience \\
\hline Human CD16 (3G8) & Fluorescein isothiocyanate & BD Bioscience \\
\hline Human CD64 (10.1) & Phycoerythrin & eBioscience \\
\hline Human PFKL (polyclonal) & Fluorescein isothiocyanate & $\begin{array}{l}\text { Aviva Systems } \\
\text { Biology }\end{array}$ \\
\hline
\end{tabular}

alntracellular staining.

with BODIPY-labeled LDL (10 $\mu \mathrm{g} / \mathrm{ml}$, Invitrogen) (16). Data were acquired and analyzed as above. CD11b ${ }^{+} \mathrm{Ly}_{6 \mathrm{C}^{\mathrm{hi}}} \mathrm{LyG}^{-}$and

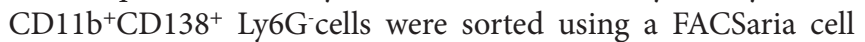
sorter and 40,000 cells/subset were lysed immediately for RNA extraction.

\section{Extracellular Flux Analysis}

For real-time analysis of mitochondrial oxygen consumption rate (OCR) and extracellular aerobic acidification rate (ECAR), peritoneal adherent cells and FACS-sorted Ly6C ${ }^{\text {hi }} \mathrm{M} \phi$ and CD138 M $\phi$ were analyzed with an XF-96 Extracellular Flux Analyzer (Seahorse Bioscience) (16). Briefly, peritoneal cells were collected by lavage from mice treated with pristane or $\mathrm{MO}$ for 14 days and stained with antibodies against CD11b, Ly6G, Ly6C, and CD138 (Table 2). CD11b Ly6G-Ly6C $^{\text {hi }} \mathrm{M} \phi$ and CD11b ${ }^{+}$Ly6G-CD $138^{+}$ M $\phi$ were sorted using a FACSAira II Cell Sorter (BD Biosciences). A total of $5 \times 10^{4}$ peritoneal cells, Ly $6 \mathrm{C}^{\text {hi }} \mathrm{M} \phi$, or $\mathrm{CD} 138^{+} \mathrm{M} \phi$ were resuspended in AIM-V medium (Thermo Fisher) and placed into 96-well XF cell culture microplates (Seahorse Bioscience). Two hours later, the cells were washed three times with warm XF assay medium and cultured in XF assay medium. Three or more consecutive measurements were obtained under basal conditions and after sequential addition of $1 \mu \mathrm{M}$ oligomycin, $0.75 \mu \mathrm{M}$ FCCP (fluoro-carbonyl cyanide phenylhydrazone), and $250 \mathrm{nM}$ rotenone plus $250 \mathrm{nM}$ antimycin A (Sigma-Aldrich).

\section{Statistical Analysis}

Statistical analyses were performed using Prism 6.0 (GraphPad Software). Differences between groups were analyzed by twosided unpaired Student's $t$-test unless otherwise indicated in the figure legend. Before comparing the means, we tested for equality of variance using the F-test. If the variances did not differ, we used Student's $t$-test. If there was statistically significant evidence that the variances differed, we used Welch's $t$-test. Data were expressed as mean $\pm \mathrm{SD}$. Correlation was analyzed using the Pearson correlation coefficient. $p<0.05$ was considered significant. All experiments in mice were repeated at least twice.

\section{RESULTS}

Diffuse alveolar hemorrhage in pristane-induced lupus is prevented by peritoneal M $\phi$ (but not neutrophil) depletion (3). In contrast, MO-treated mice do not develop DAH despite their high numbers of peritoneal $\mathrm{M} \phi$. We have shown recently that pristane treatment favors classical (M1) M $\phi$ activation whereas MO favors the generation of pro-resolving alternatively activated (M2) $\mathrm{M} \phi$ (6). We examined transcriptional activation in peritoneal $\mathrm{M} \phi$ from pristane- vs. MO-treated mice.

\section{Pristane Treatment Increases Hif1a}

M1 M $\phi$ are highly dependent on glycolytic metabolism, which is regulated by $\operatorname{HIF} 1 \alpha(15,17,22)$. In B6 mice, expression of both Hifl $a$ and the proinflammatory cytokine Tnfa was higher in PEC from pristane- vs. MO-treated mice (Figure 1A). Expression of Hifla and Tnfa correlated. As PEC from pristane- (but not MO-) treated mice contain many Ly $6 \mathrm{C}^{\text {hi }} \mathrm{CD} 11 \mathrm{~b}^{+} \mathrm{F} 4 / 80^{+}$cells (7), we determined Hifla expression in flow-sorted Ly6 $\mathrm{C}^{\text {hi }} \mathrm{CD} 11 \mathrm{~b}^{+} \mathrm{PEC}$ from pristane- and MO-treated mice. Ly $6 \mathrm{C}^{\text {hi }} \mathrm{M} \phi$ from pristanetreated mice exhibited higher levels of Hifla than Ly6C ${ }^{\text {hi }} \mathrm{M} \phi$ from MO-treated mice (Figure 1B), suggesting that glycolysis might be more active in $\mathrm{M} \phi$ from pristane- vs. MO-treated mice. The increased ECAR and decreased OCR of PEC from pristanevs. MO-treated mice in extracellular flux assays supported that hypothesis (Figures 1C,D). Consistent with the correlation between Tnfa and Hifla in PEC (Figure 1A), higher Hifla expression in the $\mathrm{Ly}_{6 \mathrm{C}} \mathrm{Ch}^{\mathrm{hi}} \mathrm{M} \phi$ subset from pristane-treated mice 

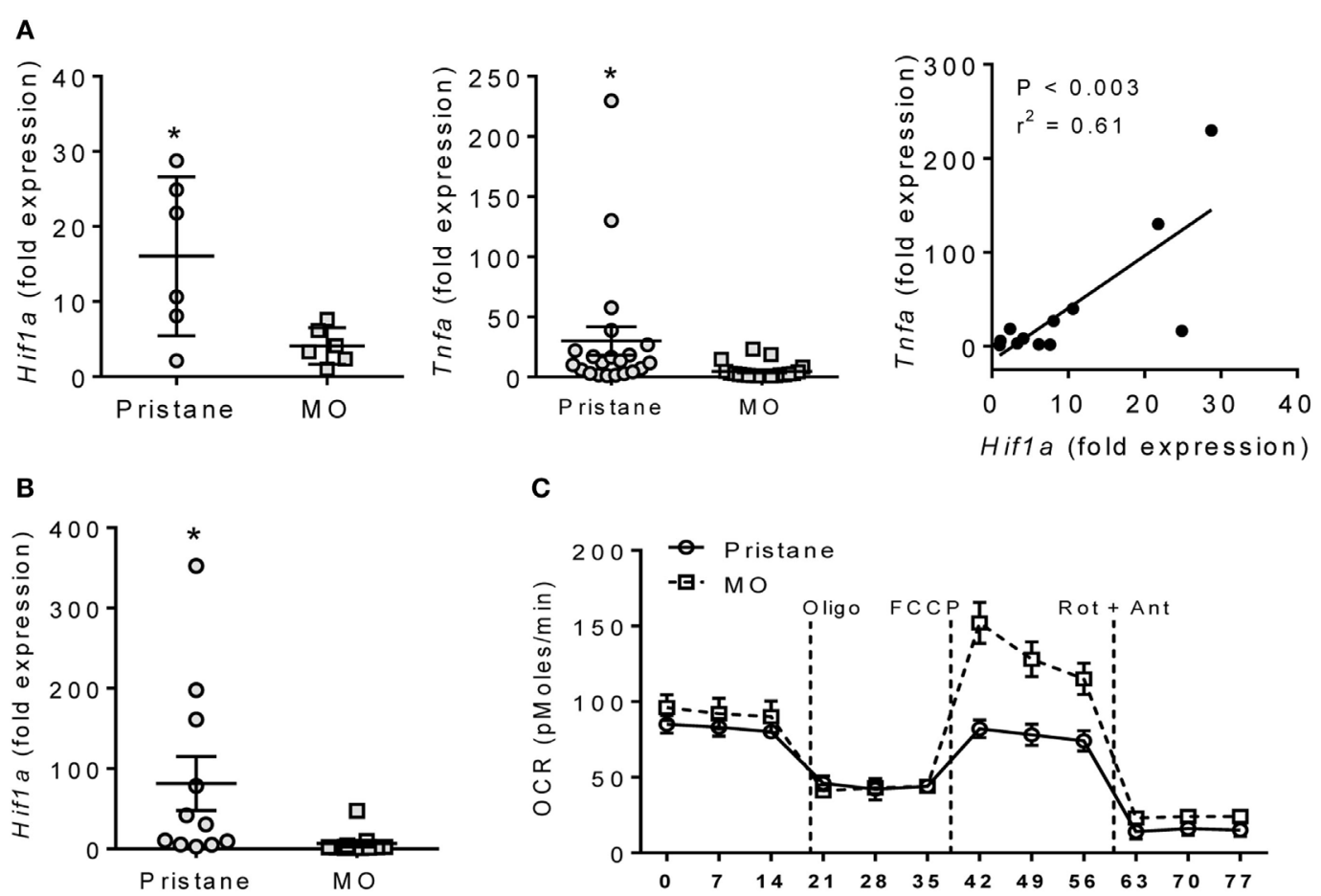

C

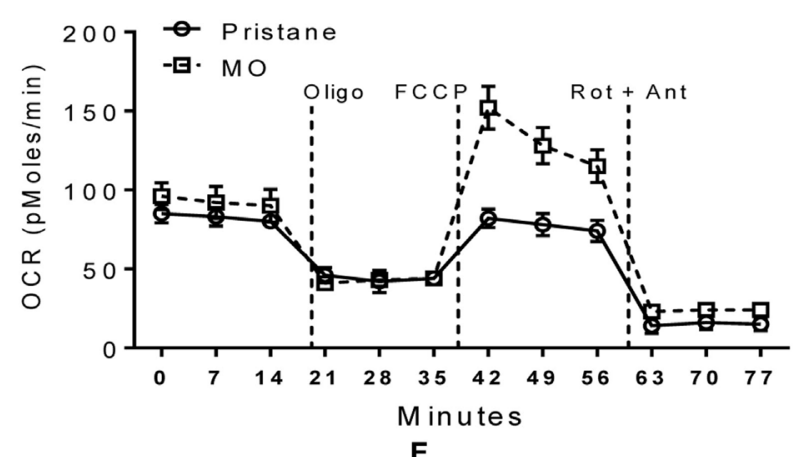

D
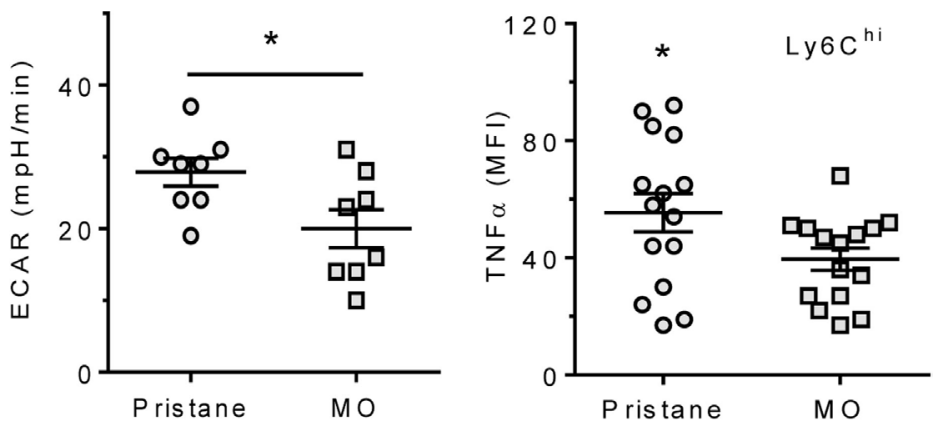

FIGURE 1 | Pristane increases HIF1 $\alpha$, TNF $\alpha$, and glycolysis. B6 mice were injected i.p. with pristane and MO. Peritoneal cells were collected at d14 and RNA was extracted. (A) Expression of Hif1a and Tnfa mRNA relative to $18 \mathrm{~S}$ (Q-PCR). ${ }^{*} P<0.05$ vs. control (unpaired Welch's $t$-test). (B) Peritoneal CD11b+Ly6Chigh cells were flow-sorted from pristane- and MO-treated mice, and Hif1a expression was measured by Q-PCR. ${ }^{*} P=0.05$ vs. control (unpaired Welch's $t$-test). (C) Extracellular flux analysis of adherent peritoneal cells from pristane- and MO-treated mice (14 days after treatment). After $1 \mathrm{~h}$ incubation, oxygen consumption rate (OCR) was determined with sequential addition of $1 \mu \mathrm{g} / \mathrm{ml}$ oligomycin (Oligo), $400 \mathrm{nM} \mathrm{FCCP}$, and $1 \mu \mathrm{M}$ rotenone $+1 \mu \mathrm{M}$ antimycin $\mathrm{A}$ (Rot + Ant). (D) Effects of pristane and MO on basal OCR (left) and extracellular acidification rate (ECAR, right) (XF96 Analyzer). Experimental treatments were performed with five technical replicates and three biological replicates. ${ }^{*} P<0.05$ vs. control (unpaired Student's $t$-test). (E) Intracellular TNF $\alpha$ staining of CD11b+Ly6C high cells from pristane vs. MO treated mice. ${ }^{\star} P<0.05$ vs. control (unpaired Student's $t$-test).

also was associated with higher intracellular staining for TNF $\alpha$ (Figures 1B,E).

\section{MO Treatment Increases LXR Activity}

Peritoneal exudate cells from MO-treated mice are enriched in M2 M $\phi(6)$. As alternatively activated M $\phi$ which depend on mitochondrial oxidative metabolism (15), the increased OCR and decreased ECAR of MO- vs. pristane-treated M $\phi$ in extracellular flux assays (Figures 1C,D) suggested an M2-like phenotype. We therefore examined the activity of $\operatorname{LXR} \alpha$, a transcription factor that regulates M2 polarization (13). Expression of Nr1h3 (encoding
LXR $\alpha$ ), increased slightly in PEC from MO-treated vs. pristanetreated mice, but it was not statistically significant. However, expression of the LXR $\alpha$-regulated gene Abca1 was substantially higher in PEC from MO-treated mice (Figure 2A). Expression levels of Abcal and Nr1h3 correlated. Treatment of PEC from wild-type mice with the LXR agonist GW3695 induced Abca1 but had only a modest effect on Nr1h3 expression (Figure 2B). Anti-inflammatory $\mathrm{CD} 138^{+} \mathrm{M} \phi$ expand in PEC from MO- vs. pristane-treated mice (6). Sorted $\mathrm{CD}_{11 \mathrm{~b}}{ }^{+} \mathrm{CD} 138^{+} \mathrm{M} \phi$ from MO-treated mice expressed higher levels of Abcal than those from pristane-treated mice and modestly higher levels of $\mathrm{Nr} 1 \mathrm{~h} 3$ 

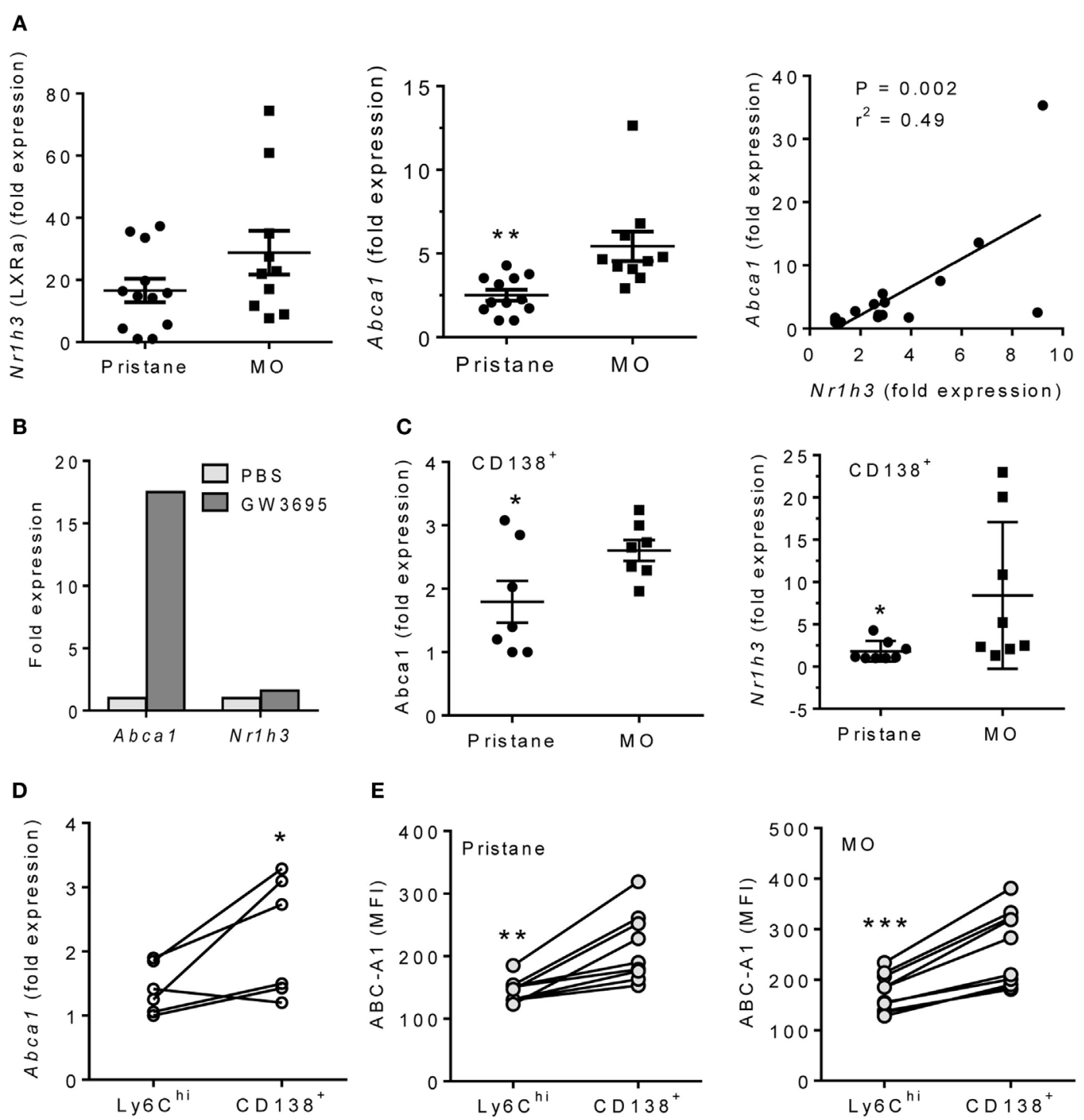

FIGURE 2 | Pristane decreases LXR $\alpha$ activity in PEC. B6 mice were injected i.p. with pristane or MO. PEC were collected at d14 and RNA was isolated. (A) Q-PCR for Nr1h3 and Abca1 expression relative to $18 \mathrm{~S}$. ${ }^{* \star} P<0.01$, Welch's $t$-test. (B) PEC from wild-type mice were stimulated with $1 \mu \mathrm{M}$ GW3965 for 24 h. Nr1h3 and Abca1 expression levels were determined by Q-PCR (representative of three experiments). (C) CD138 ${ }^{+}$CD11 b ${ }^{+}$cells from pristane- and MO-treated mice were flow sorted, and mRNA was analyzed by Q-PCR. Left, Abca1; right, Nr1h3. ${ }^{\star \star} P<0.05$, Student's $t$-test (left) and Welch's $t$-test (right). (D) Peritoneal CD11b+Ly6Chi and $\mathrm{CD} 11 \mathrm{~b}^{+} \mathrm{CD} 138^{+}$cells from MO-treated mice were flow sorted, and Abca1 expression was analyzed (Q-PCR). ${ }^{*} P<0.05$ (paired Student's $t$-test). (E) Peritoneal cells from pristane- and MO-treated mice were stained with antibodies against CD11b, CD138, Ly6C, and Abca1. Mean Fluorescence Intensity (MFI) of Abca1 staining (flow cytometry) was compared between CD11b+Ly6C ${ }^{\text {hi }}$ and CD11 b+CD138+ subsets. ${ }^{\star \star} P<0.01$; ${ }^{\star \star \star} P<0.001$ vs. control (paired Student's $t$-test).

(Figure 2C). Abcal expression was higher in sorted CD138+ $\mathrm{M} \phi$ than in $\mathrm{Ly} 6 \mathrm{C}^{\text {hi }} \mathrm{M} \phi$ from the same mouse (Figure 2D). Intracellular Abcal protein also was higher in $\mathrm{CD}_{138^{+}}$vs. Ly6C ${ }^{\text {hi }}$ $\mathrm{M} \phi$ from both pristane- and MO-treated mice (Figure 2E).

\section{Phenotypes of CD138+ $\mathrm{M} \phi$ from Pristane vs. MO Treated Mice}

Although MO-treatment favors the development of $\mathrm{CD} 138^{+}$ (pro-resolving) rather than $\operatorname{Ly} 6 \mathrm{C}^{\mathrm{hi}} \mathrm{M} \phi(6,7)$, surface staining unexpectedly revealed that the phenotypes of $\mathrm{CD} 138^{+} \mathrm{M} \phi$ from pristane- and MO-treated mice were not identical (Figure 3A). CD138 staining and staining for the M2 Mф marker CD273 were higher in $\mathrm{MO}$ - than pristane-treated mice. Conversely, staining for the M1 marker CD274, Ly6C, and CD86 was higher in $\mathrm{CD} 138^{+} \mathrm{M} \phi$ from pristane- vs. MO-treated mice (Figure 3A). By Q-PCR (Figure 3B, CD138 ${ }^{+} \mathrm{M} \phi$ from MO-treated mice expressed more Il10 and Chil3 (Ym1) and less Hif1a, Pfkl (phosphofructokinase, HIF1 $\alpha$-regulated), and Tnfa than CD $138^{+} \mathrm{M} \phi$ from pristane-treated mice. In addition, sorted $\mathrm{CD} 138^{+} \mathrm{M} \phi$ from MO-treated mice exhibited a higher OCR than $\mathrm{CD} 138^{+} \mathrm{M} \phi$ from pristane-treated mice (Figure 3C, left). In both pristane- and MO-treated mice, the OCR was higher in $\mathrm{CD} 138^{+} \mathrm{M} \phi$ than in Ly $6 \mathrm{C}^{\text {hi }} \mathrm{M} \phi$ (Figure 3C, middle and right). A similar pattern (higher in $\mathrm{CD}_{138^{+}}$vs. Ly6C ${ }^{\text {hi }} \mathrm{M} \phi$ ) was seen after staining PEC 

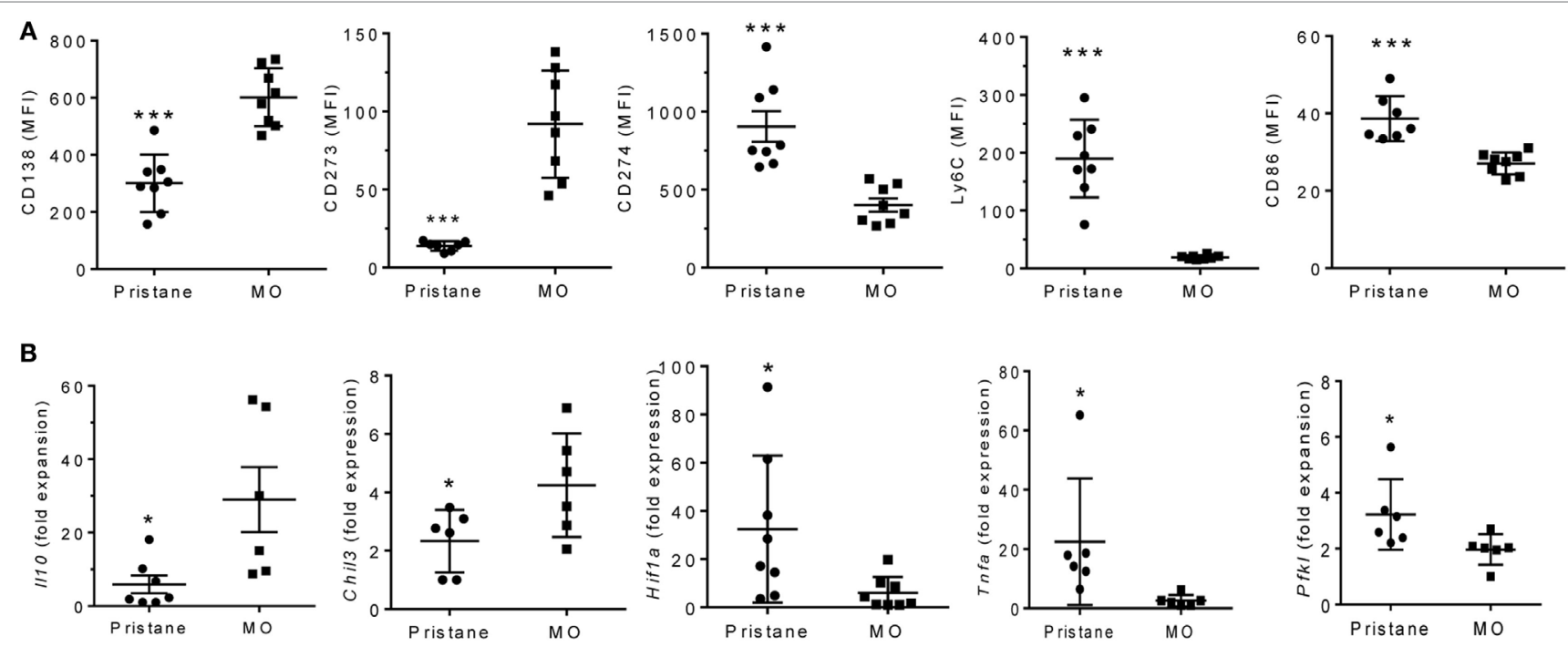

C
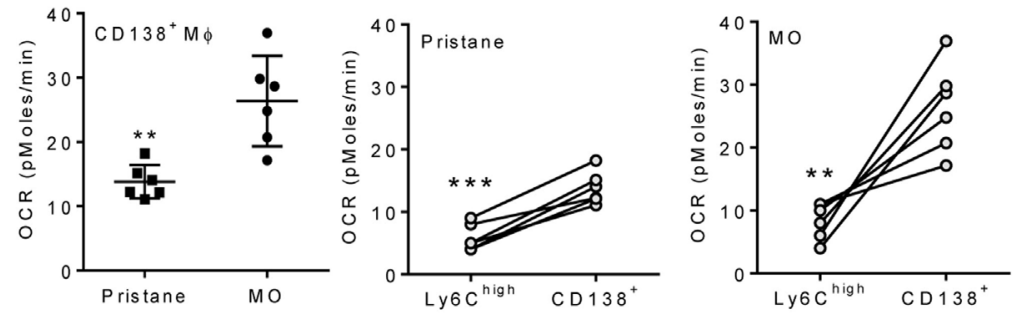

D
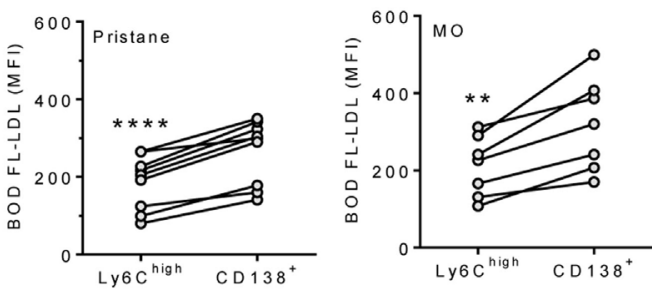

FIGURE $3 \mid \mathrm{CD}_{138^{+}} \mathrm{M}$ क in pristane-treated mice are M1-like. B6 mice were injected i.p. with pristane or mineral oil (MO). Peritoneal exudate cells were collected at d14. (A) PEC were stained with antibodies against CD11b, CD138, CD273, CD274, Ly6C, and CD86. CD11b+CD138+ cells were gated to analyze staining of the other markers. ${ }^{\star \star \star} P<0.001$ by unpaired Student's $t$-test (panels 1 and 5) or Welch's $t$-test (panels 2, 3, and 4). (B) CD11b+CD138 ${ }^{+}$cells were flow sorted, and expression levels of II10, Chil3, Tnfa, Hif1a, and Pfk/ were determined relative to $18 \mathrm{~S}$ (Q-PCR). ${ }^{*} P<0.05$ by Student's $t$-test (panels 2 and 5 ) or Welch's $t$-test (panels 1, 3, and 4). (C) Peritoneal CD11b+Ly6C ${ }^{\text {hi }}$ and CD11b+CD138+ cells were flow sorted from pristane- and MO-treated mice. OCR was measured (XF96 Analyzer). Left, CD138 $\mathrm{M \phi}$ from pristane- vs. MO-treated mice; middle and right, Ly6 $\mathrm{C}^{\text {hi }}$ vs. CD138 ${ }^{+} \mathrm{M \phi}$ from individual pristane- and MO-treated mice. Experimental treatments were performed with six technical replicates. ${ }^{* \star} P<0.01,{ }^{* \star} P<0.001$ by Welch's unpaired $t$-test (left) or Student's paired $t$-test (middle and right). (D) BODIPY-labeled LDL (10 $\mathrm{\mu g} / \mathrm{ml})$ was added to PEC from pristane- and MO-treated mice for $2 \mathrm{~h}$ and cells were then stained with anti-CD11b, Ly6C, and CD138. Mean fluorescence intensity (MFI) of BODIPY-LDL was analyzed. Comparison of Ly6C ${ }^{\text {hi }}$ vs. CD138+ Mp from individual pristane- (left) and MO- (right) treated mice ${ }^{\star \star} P<0.01 ;{ }^{\star \star \star \star} P<0.0001$ vs. control, paired Student's $t$-test.

from pristane vs. MO-treated mice with BODFL-LDL to assess uptake of exogenous LDL (Figure 3D). Overall, CD138+ $\mathrm{M} \phi$ from $\mathrm{MO}$-treated mice were more M2-like than the $\mathrm{CD} 138^{+} \mathrm{M} \phi$ subset from pristane-treated mice and in comparison with the Ly6C $^{\text {hi }}$ subset, CD138+ M $\phi$ were more M2-like.

\section{Inverse Relationship of HIF-1 $\alpha$ and $\mathrm{LXR} \alpha$ Expression in Lupus Mice}

Although $\mathrm{CD} 138^{+} \mathrm{M} \phi$ from lupus (pristane-treated) mice were more "inflammatory" than those from MO-treated controls, Hifla expression was still higher in peritoneal M1-like Ly6C ${ }^{\text {hi }}$ than in $\mathrm{M} 2$-like $\mathrm{CD} 138^{+} \mathrm{M} \phi$ from pristane-treated mice (Figure 4A). Hif1a mRNA levels correlated inversely with Abca1 in pristanetreated mice (Figure 4B). Expression of the HIF-1 $\alpha$ regulated genes Pfkl $(23,24)$ and G6pd (glucose-6-phosphate dehydrogenase) (25) (but not Hk2) was higher in pristane- vs. MO-treated mice (Figure 4C). To see if LXR activation downregulates Hifla, peritoneal M $\phi$ from pristane-treated mice were treated for $24 \mathrm{~h}$ with the LXR agonist GW3965, which decreased expression of Hifla as well as Pfkl, but not hexokinase-2 (Hk2) (Figure 4D). As expected, expression of the LXR-regulated Abcal gene increased after GW3965 treatment. These data suggested that treatment with LXR agonists might normalize HIF- $1 \alpha$ activity in $\mathrm{M} \phi$ from pristane-treated mice. We therefore examined the possibility of treating DAH using LXR agonists to induce M $\phi$ repolarization.

\section{LXR Agonist Therapy Prevents DAH}

LXR agonists include naturally occurring oxysterols and synthetic ligands, such as GW3965 and T0901317 (26). In vitro treatment with GW3965 or T0901317 increased OCR in RAW-264.7 cells (Figure 5A) and adherent peritoneal $\mathrm{M} \phi$ from pristane-treated mice (Figure 5B), suggesting that LXR activation promotes alternative activation.

We treated B6 mice with pristane (d0) plus daily injections of either T0901317 or vehicle and assessed DAH at d14. Daily T0901317 treatment for 14 days completely protected the 

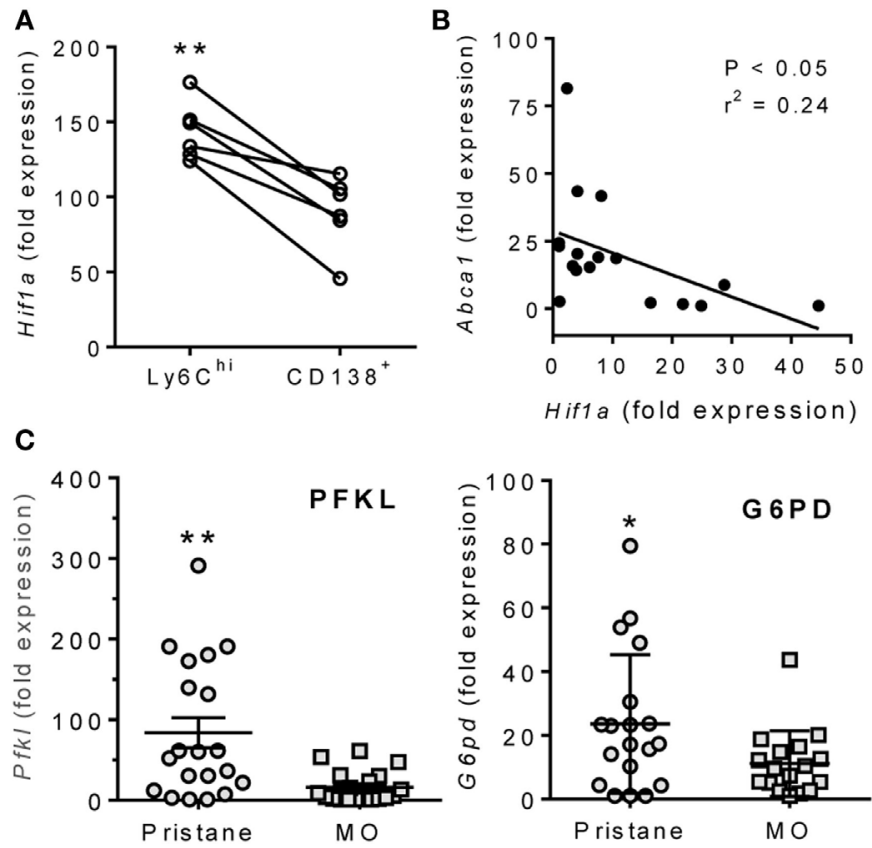
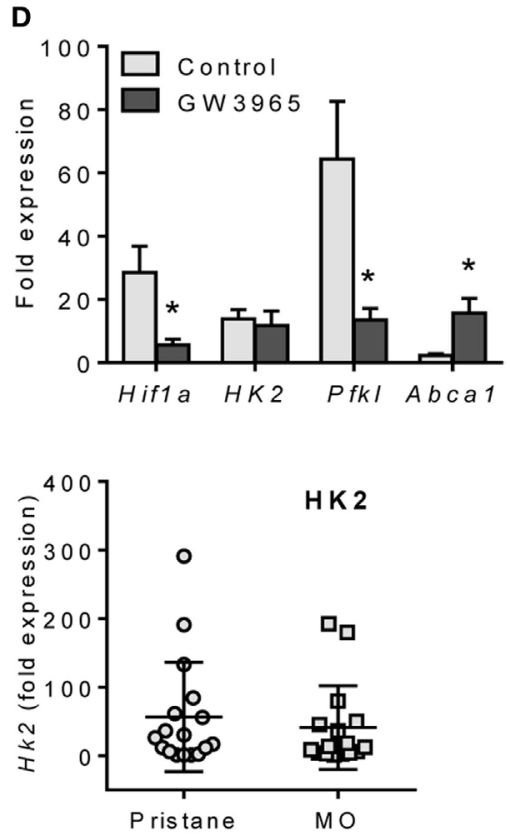

FIGURE 4 | Inverse relationship of LXR $\alpha$ and HIF-1 $\alpha$. (A) Peritoneal Ly6C ${ }^{\text {hi }}$ and CD138+ M $\phi$ were flow sorted from pristane-treated mice, and Hif1a mRNA expression was measured relative to $18 \mathrm{~S}(\mathrm{Q}-\mathrm{PCR}) .{ }^{\star \star} P<0.01$, Student's paired $t$-test. (B) Inverse relationship of Hif1a and Abca1 mRNA levels in PEC from pristane-treated mice. (C) PEC were collected 14 days after pristane- or MO-treatment and expression of HIF1 $\alpha$-regulated genes (Pfkl, G6pd, and Hk2) was measured (Q-PCR) ( ${ }^{\star} P<0.05$, unpaired Welch's $t$-test). (D) Adherent peritoneal cells from pristane-treated mice were incubated with GW3965 or DMSO for 24 h, and expression levels of Hif1a, Hk2, Pfkl, and Abca1 mRNA were measured relative to $18 \mathrm{~S}$ (Q-PCR). $\left({ }^{\star} P<0.05\right.$, ${ }^{\star \star} P<0.01$, unpaired Welch's $t$-test).

mice from lung hemorrhage (Figure 5C). Mice treated from $\mathrm{d} 1-\mathrm{d} 3$ or $\mathrm{d}-\mathrm{d} 14$ may exhibit partial protection, but this did not reach statistical significance. Treatment from d7-d14 had no effect. As expected, intracellular Abcal staining was higher in $\mathrm{CD}_{11} \mathrm{~b}^{+} \mathrm{CD} 138^{+} \mathrm{M} \phi$ from T0901317-treated mice than in controls (Figure 5D). T0901317 also decreased surface CD11b and intracellular TNF $\alpha$ staining in $\mathrm{CD} 11 \mathrm{~b}^{+} \mathrm{CD} 138^{+} \mathrm{M} \phi$ (Figure 5E).

\section{Expression of HIF-1 $\alpha$ and LXR $\alpha$ in SLE Patients}

The altered expression of LXR $\alpha$ and HIF- $1 \alpha$ in mice with pristane-lupus prompted us to look for similar changes in circulating monocytes from SLE patients. NR1H3 and ABCA 1 expression levels were lower in adherent PBMCs from 22 consecutively seen SLE patients vs. 24 healthy controls (Figure 6A). As in pristaneinduced lupus, $N R 1 H 3$ and $A B C A 1$ expression correlated in humans (Figure 6A). GW3965 treatment induced $A B C A 1$ and NR1H3 expression in adherent PBMCs from healthy controls (Figure 6B). As in mice, HIF1A and PFKL expression levels were higher in adherent PBMCs from SLE patients vs. healthy controls (Figures 6C,D).

Systemic lupus erythematosus is associated with overproduction of IFN $\alpha / \beta$ (27). In the 22 consecutive SLE patients, CD64 fluorescence intensity on $\mathrm{CD}^{+} 4^{+}$cells, a marker of IFN $\alpha / \beta$ stimulation (28), was inversely associated with $A B C A 1$ expression (Q-PCR) (Figure 6E). CD64 surface staining also correlated inversely with ABCA1 intracellular staining intensity (flow cytometry) (Figure 6F). SLE patients with a SLEDAI $\geq 3$ had low ABCA1 and high CD64 staining, whereas healthy controls exhibited the opposite pattern (Figure 6G).

To further examine the effects of LXR $\alpha$ activation on proinflammatory cytokines, we treated adherent PBMCs from healthy donors with IFN $\alpha$ or IFN $\alpha+$ GW3965 (Figure 7). GW3965 reduced expression of the IFN-I inducible genes MX1 and LY6E (Figure 7A) and reduced fluorescence intensity of the IFN-I inducible surface markers CD64 and CD16 on CD14 ${ }^{+}$peripheral blood monocytes (Figure 7B), suggesting that LXR activation may downregulate the expression of interferon-regulated genes (interferon signature).

\section{DISCUSSION}

$\mathrm{CD} 138^{+} \mathrm{M} \phi$, which are highly phagocytic for apoptotic cells and promote the resolution of inflammation, are deficient in mice with pristane-induced lupus (6). This deficiency impairs the clearance of dead cells, a defect also seen in monocyte-derived M $\phi$ from SLE patients (29). We explored the possibility of treating lupus by enhancing the generation of these phagocytic CD $138^{+}$ $\mathrm{M} \phi$. Consistent with their M2-like phenotype (6), $\mathrm{CD}_{138^{+} \mathrm{M} \phi}$ from MO-treated mice had a metabolic profile consistent with alternatively activated $\mathrm{M} \phi$ and expressed high levels LXR $\alpha$, a transcription factor implicated in generating M2 M $\phi$ (13). In contrast, $\mathrm{CD} 138^{+} \mathrm{M} \phi$ from pristane-treated mice were M1-like, expressing low levels of LXR $\alpha$ and high levels of HIF1 $\alpha$, a 

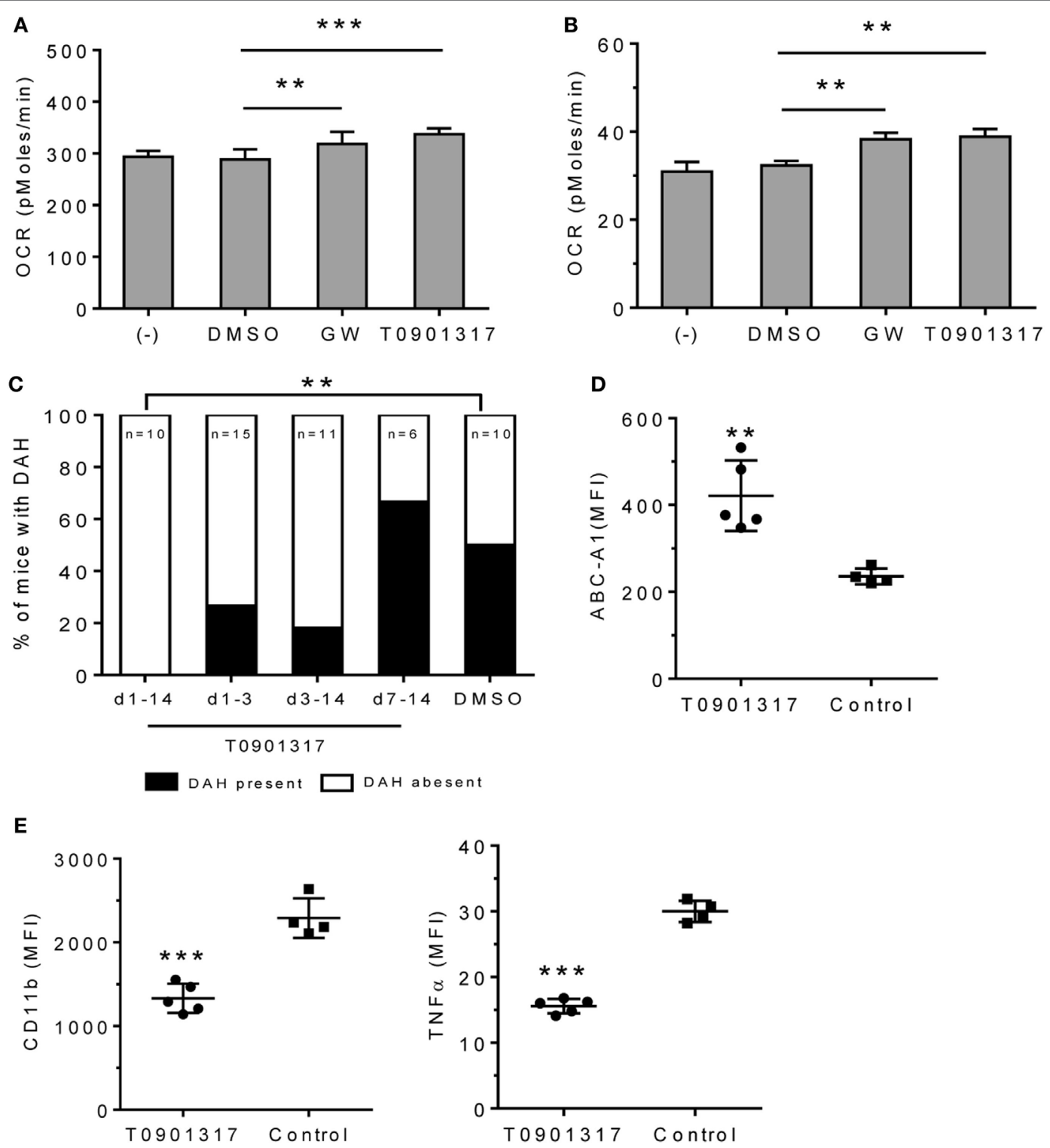

FIGURE 5 | Effect of LXR $\alpha$ agonist on pristane-induced lung hemorrhage. (A) In vitro treatment of RAW-264.7 cells with GW3965 (GW, 1 $\mu$ M), T0901317 $(1 \mu \mathrm{M})$, or DMSO for $24 \mathrm{~h}$. Oxygen consumption rate (OCR) was measured (XF96 Analyzer). Experimental treatments were performed with six technical replicates. ${ }^{\star \star} P<0.01 ;{ }^{* \star \star} P<0.001$ vs. control (Student's unpaired $t$-test). (B) Adherent peritoneal M $\phi$ from pristane-treated B6 mice were incubated for $24-\mathrm{h}$ with GW3965, T0901317, or DMSO followed by measurement of OCR. Experimental treatments were performed with six technical replicates. ${ }^{\star \star} P<0.01$ vs. control (Student's unpaired t-test). (C-E), B6 mice were injected once with pristane and treated i.p. with T0901317 (200 $\mu \mathrm{g} / \mathrm{mouse} / \mathrm{day})$ or DMSO ( $n=10)$ starting on the day of pristane treatment. One group received T0901317 daily from d1-d14 $(n=10)$, another from d1-d3 $(n=15)$, another from d3-d14 $(n=11)$, and another from d7-d14 $(n=6)$. (C) Frequency of lung hemorrhage in the four groups. 5/10 control mice and 0/10 mice treated with T0901317 (d1-d14) developed DAH ( $\left.{ }^{\star \star} P<0.01, \chi^{2}\right)$. (D, E) Flow cytometry of CD11b+CD138+ M申 from mice treated with pristane plus T0901317 (d1-d14) vs. DMSO (Control). MFI, mean fluorescence intensity. (D) Intracellular staining for Abca1 in CD11 $\mathrm{b}^{+} \mathrm{CD} 138+$ cells. ${ }^{* *} P<0.01 \mathrm{vs}$. control (Welch's unpaired $t$-test).

(E), Surface staining for CD11b and intracellular staining for TNF $\alpha$. CD11 b+CD138+ cells were gated to analyze the expression level (MFI) of CD11b and TNF $\alpha$. ${ }^{\star} P<0.05 ;{ }^{* \star \star} P<0.001$ vs. control (Student's unpaired $t$-test).

transcription factor that promotes glycolytic metabolism and the generation of M1 M $(17,22)$. Treatment of mice with pristaneinduced lupus using an LXR agonist enhanced the expression of M2 M $\phi$ markers and prevented DAH, a severe inflammatory lung disease associated with pulmonary vasculitis that occurs in $3 \%$ of SLE patients $(4,30)$. Like PECs from pristane-treated mice, peripheral blood monocytes from SLE patients exhibited high HIF $1 \alpha$ and low LXR $\alpha$ activity and LXR agonist treatment attenuated the interferon signature in these cells. The data suggest that abnormal $\mathrm{M} \phi$ polarization contributes to the pathogenesis of SLE and that correcting the imbalance between M1- and M2-like Mф polarization may be a useful therapeutic strategy. 

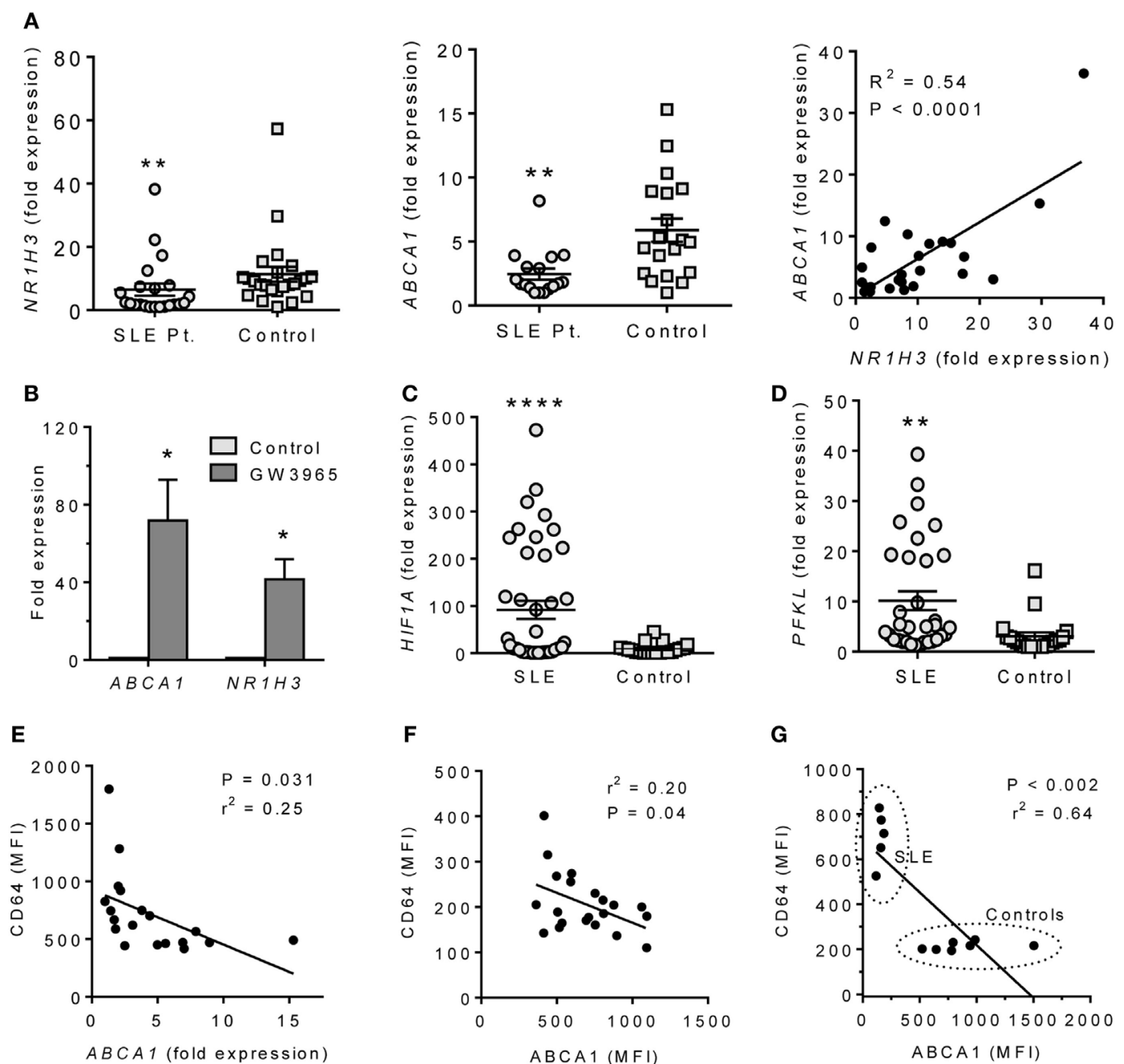

FIGURE 6 | ABCA1 and HIF1 $\alpha$ expression in monocytes from SLE patients. (A) Expression of NR1H3 and ABCA1 in adherent PBMC (Q-PCR) and bivariate analysis of $A B C A 1$ vs. $N R 1 H 3$ (right). Left ${ }^{* \star} P<0.01$ (Student's unpaired $t$-test); Middle, ${ }^{* \star} P<0.01$ vs. control (Welch's unpaired $t$-test). (B) Adherent PBMCs were treated with $1 \mu \mathrm{M}$ GW3965 or vehicle alone (Control) for $24 \mathrm{~h}$. $A B C A 1$ and NR1H3 expression levels were measured by Q-PCR. ${ }^{*} P<0.05$ (Welch's unpaired $t$-test). (C) Expression of HIF1A in adherent PBMCs from SLE patients vs. healthy controls (Q-PCR). ${ }^{*} P<0.0001$ (Welch's unpaired $t$-test). (D) $P F K L$ expression on adherent PBMCs from SLE and healthy controls (Q-PCR). ${ }^{*} P<0.01$ (Welch's unpaired $t$-test). (E) Flow cytometry of the IFN-regulated protein CD64 staining (MFI, flow cytometry) vs. ABCA1 mRNA expression (Q-PCR) in monocytes from unselected SLE patients. (F) Flow cytometry of CD64 (surface staining) vs. ABCA1 (intracellular staining) in monocytes from unselected SLE patients. (G) CD64 vs. ABCA1 staining in PBMCs from five patients with active SLE and seven healthy controls.

\section{M1-M2 M $\phi$ Imbalance in Pristane-Induced Lupus}

We reported recently that a novel subset of $\mathrm{CD} 138^{+} \mathrm{M} \phi$ with an M2 phenotype is highly phagocytic for apoptotic cells and promotes the resolution of inflammation. This subset is deficient in pristane-treated mice in comparison with MO-treated controls (6). In contrast, the M1-like Ly6C $\mathrm{C}^{\text {hi }} \mathrm{M} \phi$ subset expands in pristane-treated mice. M1 M $\phi$ rely on glycolysis (high ECAR) whereas M2 M申 rely on fatty acid oxidation (high OCR) $(15,16)$. $\mathrm{M} \phi$ from MO-treated mice had higher OCR, whereas ECAR was higher in pristane-treated mice (Figure 1), consistent with expansion of the M1 subset in pristane-induced lupus. Unexpectedly, CD138 ${ }^{+} \mathrm{M} \phi$ from MO-treated mice had a higher OCR and expressed higher levels of M2 M $\phi$ markers [CD273,
Chil3 (Ym1), and IL-10] than those from pristane-treated mice, which preferentially expressed the M1 markers CD274, CD86, and TNF $\alpha$ (Figure 3). Thus, either the phenotype of $\mathrm{CD}_{138^{+} \mathrm{M} \phi}$ subset exhibits some plasticity or there is more than one subset of $\mathrm{CD} 138^{+} \mathrm{M} \phi$. Our recent studies suggest the presence of an additional subset of proinflammatory $\mathrm{CD} 138^{+}$monocyte/M $\phi$ in pristane-treated B6 mice (S Han, unpublished data). Since HIF1 $\alpha$ and LXR $\alpha$ regulate the gene expression programs of M1 and M2 $\mathrm{M} \phi$, respectively, we examined the activity of these transcription factors in pristane- vs. MO-treated mice.

\section{High HIF1 $\alpha$ Activity in Lupus}

Hypoxia-inducible factor $1-\alpha$ and HIF $1 \alpha$-regulated genes were expressed at higher levels in both murine and human lupus 

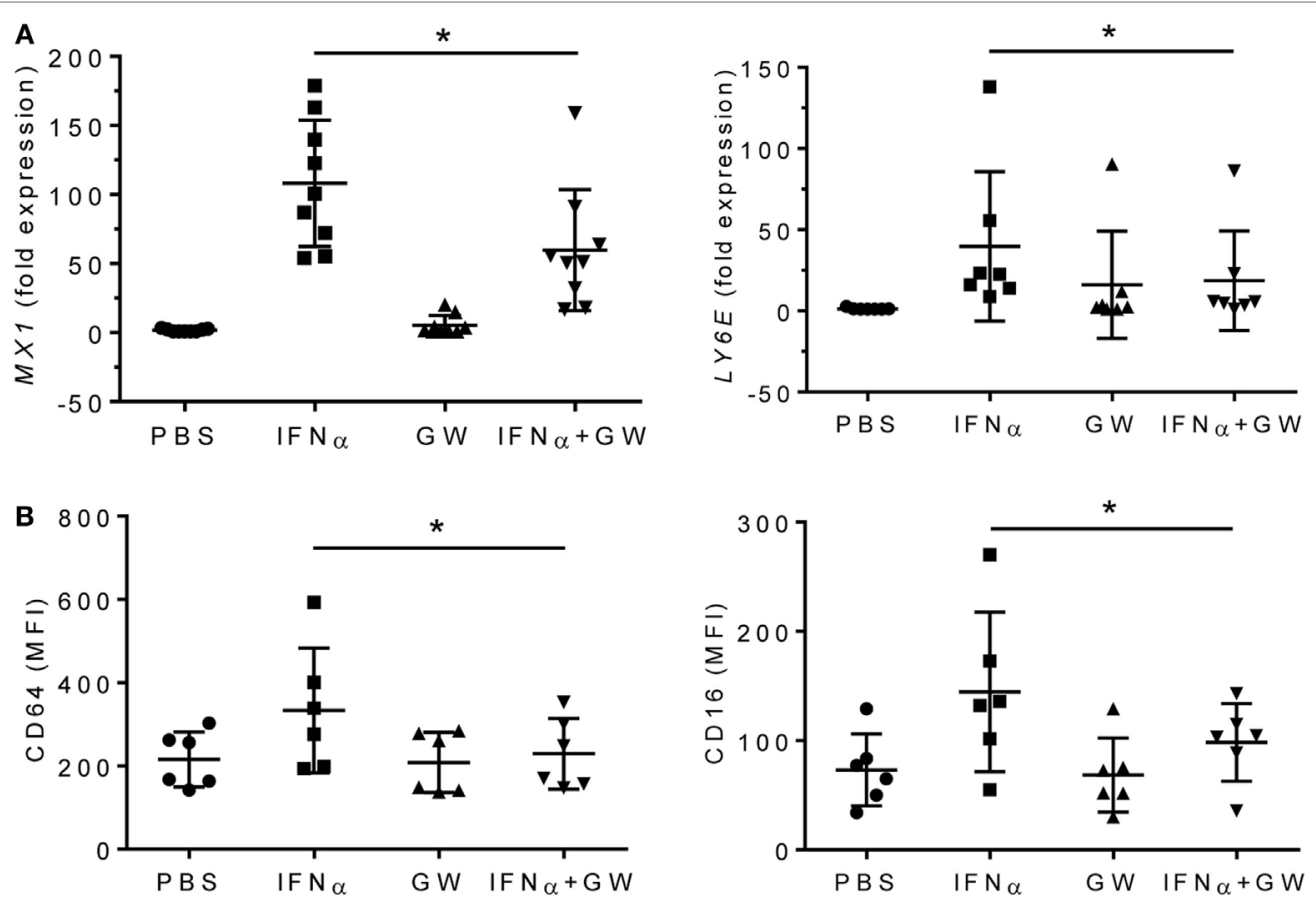

FIGURE 7 | LXR agonist attenuates the type I interferon signature. Adherent PMBCs from healthy donors were incubated for $24 \mathrm{~h}$ with IFN $(1,000 \mathrm{U} / \mathrm{ml})$, GW3965 (GW, $1 \mu \mathrm{M}$ ), or both. (A), mRNA levels of $M X 1$ and $L Y 6 E$ were measured by Q-PCR. (B) CD64 and CD16 staining (mean fluorescence intensity, MFI) was determined by flow cytometry. ${ }^{*} P<0.05$ vs. control (unpaired Student's $t$-test).

(Figures 4 and 6). HIF1 $\alpha$ is a hypoxia-induced regulator of glycolytic enzymes (e.g., HK2, PFKL, and G6PD) (17), and an inducer of M1 activation and the production of TNF $\alpha$ and other proinflammatory cytokines $(18,31)$. Heterodimers of HIF $1 \alpha$ with the constitutively expressed aryl hydrocarbon receptor nuclear translocator bind and transactivate target genes containing hypoxia response elements (17). The transcriptional program induced by HIF1 $\alpha$ is important for $\mathrm{M} \phi$ and neutrophil function in infected (hypoxic) tissues (32). HIF targets include genes involved in aerobic glycolysis as well as inflammation $(17,33)$. The M1 marker CD274 (PD-L1) is HIF1 $\alpha$ regulated and was expressed at higher levels in $\mathrm{M} \phi$ from pristane- vs. MO-treated mice (Figure 3A).

\section{Impaired LXR $\alpha$ Activity in Lupus}

In contrast to HIF1 $\alpha, \mathrm{LXR} \alpha$ promotes M2 M development $(13,34)$. Hifla mRNA expression correlated positively with Tnfa (Figure 1A) and inversely with the LXR-regulated gene Abcal (Figure 4B). Transcription factors of the LXR family form heterodimers with the retinoid $\mathrm{X}$ receptor, are activated by oxysterols (e.g., 25-hydroxycholesterol) (12), and regulate the transport of cholesterol transport to the liver and its biliary excretion $(26,35)$. Following uptake of apoptotic cells, oxysterols from the cell membranes activate the LXR pathway, upregulating the apoptotic cell receptor MerTK (14) and genes involved in cholesterol efflux (e.g., $A B C A 1$ ). LXR activation downregulates innate immunity and inflammation by suppressing TLR signaling in $M \phi$ $(12,36)$. This may be one reason that phagocytosis of apoptotic cells is usually anti-inflammatory. Mice doubly deficient in LXR $\alpha$ and LXR $\beta$ exhibit proinflammatory signaling in response to apoptotic cells and develop lupus-like disease (14).

LXR activation is critical for M2 M $\phi$ polarization, expression of M2 signature genes, and downregulation of inflammation in activated Mф (34). In both pristane-induced lupus and SLE patients, expression of the LXR-regulated gene ABCA1 was impaired at both the RNA and protein level (Figures 2A and 6A). Lupus and control M $\phi$ did not exhibit substantially different Nr1h3 gene expression, suggesting that the low Abcal levels in lupus mice reflect impaired activation of LXR protein rather than low Nr3h1 mRNA levels. However, our studies did not address the issue of whether the observed differences in $\mathrm{M} \phi$ function specifically reflect the expression level of ABCA1 gene/protein or if the expression of other LXR-regulated genes plays a role. In mice, low LXR $\alpha$ was associated with high levels of TNF $\alpha$ and

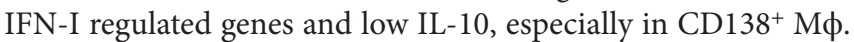
In human monocytes, LXR agonists inhibited the induction of MX1 and other type I IFN-stimulated genes by IFN $\alpha$ (Figure 7). Inhibition of Hifla and Pfkl gene expression by LXR agonists (Figure 4C) further suggests that LXR may cross-regulate the HIF pathway, providing a potential mechanism for switching from M1 to M2 polarization.

\section{LXR Agonist Treatment Prevents DAH in Lupus}

Our data suggested that HIF1 $\alpha$ inhibitors or LXR agonists might benefit lupus patients by promoting M2 M $\phi$ polarization. 
Selective HIF1 $\alpha$ inhibitors are not readily available, although there is interest in targeting the HIF $1 \alpha$ activation pathway for cancer therapy $(33,37)$. Synthetic LXR agonists protect mice from atherosclerosis, myocardial ischemia-perfusion injury, and other conditions $(26,38)$. Unfortunately, their clinical use is complicated by hepatic steatosis, degradation of hepatic LDL receptors via the LXR-IDOL (inducible degrader of the LDL receptor) pathway, and/or unexplained neurological side effects $(26,38)$. However, the development of safer LXR agonists for clinical use is ongoing.

We gave pristane-treated mice the LXR agonist T0901317 to see if it could prevent DAH, an often fatal complication of SLE $(2,3)$. Daily LXR agonist treatment protected mice from DAH and promoted $\mathrm{M} 2$ repolarization of $\mathrm{CD} 138^{+} \mathrm{M} \phi$ (Figure 5), suggesting that M1 M $\phi$ play a role in SLE-associated DAH. As DAH is similar in pristane-induced and human lupus (3), LXR agonists also might be useful in patients with DAH. We speculate that LXR agonists also might have a role in treating other $\mathrm{M} \phi$-mediated clinical manifestations of lupus. In lupus nephritis patients, glomerular and tubular $\mathrm{M} \phi$ are among the best early correlates of proteinuria, declining creatinine, and poor renal outcome $(39,40)$. M $\phi$ also promote lupus nephritis in NZB/W mice $(41,42)$. Thus, lupus nephritis is a potential target for future testing of LXR-agonist therapy.

Low LXR expression also may be involved in accelerated atherosclerosis in SLE (43). Non-resolving inflammation in the vessel wall mediated by infiltrating $\mathrm{M} \phi$ plays a central role in atherosclerosis and LXRs reciprocally regulate inflammation and lipid metabolism $(34,44)$. Similar to pristane-induced lupus (6), chronic inflammation in atherosclerotic plaques is associated with decreased non-inflammatory clearance of apoptotic cells by M $\phi$ (45). Thus, the LXR pathway may have far-reaching effects on the pathogenesis of organ damage in SLE.

Impaired M $\phi$-mediated uptake of apoptotic cells is strongly associated with both human and murine lupus $(6,21,29,46)$. LXR signaling upregulates the clearance of apoptotic cells and its absence promotes autoimmunity (14). The present study provides the first evidence that LXR activity is abnormally low in monocytes/M $\phi$ from SLE patients whereas activity of HIF $1 \alpha$, a transcription factor that promotes inflammation and M1 polarization, is increased. The data support the clinical relevance of defective M1-M2 polarization, impaired apoptotic cell clearance,

\section{REFERENCES}

1. Reeves WH, Lee PY, Weinstein JS, Satoh M, Lu L. Induction of autoimmunity by pristane and other naturally occurring hydrocarbons. Trends Immunol (2009) 30:455-64. doi:10.1016/j.it.2009.06.003

2. Barker TT, Lee PY, Kelly-Scumpia KM, Weinstein JS, Nacionales DC, Kumagai Y, et al. Pathogenic role of B cells in the development of diffuse alveolar hemorrhage induced by pristane. Lab Invest (2011) 91:1540-50. doi:10.1038/labinvest.2011.108

3. Zhuang H, Han S, Lee PY, Khaybullin R, Shumyak S, Lu L, et al. Pathogenesis of diffuse alveolar hemorrhage in murine lupus. Arthritis Rheumatol (2017) 69:1280-93; (see commentary). doi:10.1002/art.40077

4. Zamora MR, Warner ML, Tuder R, Schwarz MI. Diffuse alveolar hemorrhage and systemic lupus erythematosus. Clinical presentation, histology, survival, and outcome. Medicine (1997) 76:192-202. doi:10.1097/00005792-199705000-00005 and non-resolving inflammation seen in pristane-induced lupus (6) and indicate that LXR agonist therapy aimed at repolarizing $\mathrm{M} \phi$ can prevent disease, suggesting that a similar response may be achievable in SLE patients. LXR agonists modulated type I interferon production (Figure 7) and there is evidence for interplay between LXR signaling and Type I/Type II interferon production (47-49). However, LXR agonists are likely to have additional, interferon-independent, effects in lupus, since Type I interferon does not play a major role in the pathogenesis of DAH (3). It will be of interest to elucidate how signaling pathways downstream of LXR modulate the inflammatory response in lupus patients. Finally, the results identify imbalanced HIF $1 \alpha$ and $\operatorname{LXR} \alpha$ activity as a potential biomarker for assessing chronic inflammation in SLE patients and the response to anti-inflammatory therapy.

\section{AUTHOR CONTRIBUTIONS}

$\mathrm{SH}$ : Acquired the data and assisted in the analysis and interpretation and preparation of the manuscript. HZ: Acquired the data and assisted in the analysis and interpretation. SS: Assisted with data acquisition and analysis. JW: Assisted with data acquisition and analysis. CX: Assisted with data acquisition and analysis. HL: Assisted with data acquisition and analysis. LY: Assisted with data interpretation and preparation of the manuscript. WR: Responsible for the overall design of the study, analysis and interpretation of the data, and manuscript preparation.

\section{ACKNOWLEDGMENTS}

We are grateful to Matthew Robinson, M.Sc. (University of Florida, Clinical and Translational Research Institute) for advice on statistical analysis.

\section{FUNDING}

Supported by research grants R01-AR44731 from NIH/NIAMS and the Lupus Research Institute (LY). Research reported in this publication was supported by the National Center for Advancing Translational Sciences of the National Institutes of Health under Award Number UL1TR001427. The content is solely the responsibility of the authors and does not necessarily represent the official views of the National Institutes of Health.

5. Nathan C, Ding A. Nonresolving inflammation. Cell (1997) 140:871-82. doi:10.1016/j.cell.2010.02.029

6. Han S, Zhuang H, Shumyak S, Wu J, Li H, Yang LJ, et al. A novel subset of anti-inflammatory CD138+ macrophages is deficient in mice with experimental lupus. J Immunol (2017) 199:1261-74; (see commentary). doi:10.4049/ jimmunol.1700099

7. Lee PY, Weinstein JS, Nacionales DC, Scumpia PO, Li Y, Butfiloski E, et al. A novel type I IFN-producing cell subset in murine lupus. J Immunol (2008) 180:5101-8. doi:10.4049/jimmunol.180.7.5101

8. Murray PJ, Allen JE, Biswas SK, Fisher EA, Gilroy DW, Goerdt S, et al. Macrophage activation and polarization: nomenclature and experimental guidelines. Immunity (2014) 41:14-20. doi:10.1016/j.immuni.2014.06.008

9. Martinez FO, Gordon S. The M1 and M2 paradigm of macrophage activation: time for reassessment. F1000Prime Rep (2014) 6:13. doi:10.12703/ P6-13 
10. Ivashkiv LB. Epigenetic regulation of macrophage polarization and function. Trends Immunol (2013) 34:216-23. doi:10.1016/j.it.2012.11.001

11. Ruffell D, Mourkioti F, Gambardella A, Kirstetter P, Lopez RG, Rosenthal N, et al. EBPbeta cascade induces M2 macrophage-specific gene expression and promotes muscle injury repair. Proc Natl Acad Sci U S A (2009) 106:17475-80. doi:10.1073/pnas.0908641106

12. Spann NJ, Glass CK. Sterols and oxysterols in immune cell function. Nat Immunol (2013) 14:893-900. doi:10.1038/ni.2681

13. Kimura T, Nada S, Takegahara N, Okuno T, Nojima S, Kang S, et al. Polarization of M2 macrophages requires Lamtor1 that integrates cytokine and aminoacid signals. Nat Commun (2016) 7:13130. doi:10.1038/ncomms13130

14. A-Gonzalez N, Bensinger SJ, Hong C, Beceiro S, Bradley MN, Zelcer N, et al. Apoptotic cells promote their own clearance and immune tolerance through activation of the nuclear receptor LXR. Immunity (2009) 31:245-58. doi:10.1016/j.immuni.2009.06.018

15. Ganeshan K, Chawla A. Metabolic regulation of immune responses. Annu Rev Immunol (2014) 32:609-34. doi:10.1146/annurev-immunol-032713-120236

16. Huang SC, Everts B, Ivanova Y, O'Sullivan D, Nascimento M, Smith AM, et al. Cell-intrinsic lysosomal lipolysis is essential for alternative activation of macrophages. Nat Immunol (2014) 15:846-55. doi:10.1038/ni.2956

17. Corcoran SE, O'Neill LA. HIFlalpha and metabolic reprogramming in inflammation. J Clin Invest (2016) 126:3699-707. doi:10.1172/JCI84431

18. Tannahill GM, Curtis AM, Adamik J, Palsson-McDermott EM, McGettrick AF, Goel G, et al. Succinate is an inflammatory signal that induces IL-1beta through HIF-1alpha. Nature (2013) 496:238-42. doi:10.1038/nature11986

19. Tan EM, Cohen AS, Fries JF, Masi AT, McShane DJ, Rothfield NF, et al. The 1982 revised criteria for the classification of systemic lupus erythematosus. Arthritis Rheum (1982) 25:1271-7. doi:10.1002/art.1780251101

20. Bombardier C, Gladman DD, Urowitz MB, Caron D, Chang CH. Derivation of the SLEDAI: a disease activity index for lupus patients. The Committee on Prognosis Studies in SLE. Arthritis Rheum (1992) 35:630-40. doi:10.1002/ art.1780350606

21. Zhuang H, Han S, Xu Y, Li Y, Wang H, Yang LJ, et al. Toll-like receptor 7stimulated tumor necrosis factor alpha causes bone marrow damage in systemic lupus erythematosus. Arthritis Rheumatol (2014) 66:140-51. doi:10.1002/art.38189

22. Galvan-Pena S, O'Neill LA. Metabolic reprograming in macrophage polarization. Front Immunol (2014) 5:420. doi:10.3389/fimmu.2014.00420

23. Obach M, Navarro-Sabate A, Caro J, Kong X, Duran J, Gomez M, et al. 6-Phosphofructo-2-kinase (pfkfb3) gene promoter contains hypoxiainducible factor-1 binding sites necessary for transactivation in response to hypoxia. J Biol Chem (2004) 279:53562-70. doi:10.1074/jbc.M406096200

24. Semenza GL, Roth PH, Fang HM, Wang GL. Transcriptional regulation of genes encoding glycolytic enzymes by hypoxia-inducible factor 1. J Biol Chem (1994) 269:23757-63.

25. Gao L, Mejias R, Echevarria M, Lopez-Barneo J. Induction of the glucose6-phosphate dehydrogenase gene expression by chronic hypoxia in PC12 cells. FEBS Lett (2004) 569:256-60. doi:10.1016/j.febslet.2004.06.004

26. Ma Z, Deng C, Hu W, Zhou J, Fan C, Di S, et al. Liver X receptors and their agonists: targeting for cholesterol homeostasis and cardiovascular diseases. Curr Issues Mol Biol (2017) 22:41-64. doi:10.21775/cimb.022.041

27. Bennett L, Palucka AK, Arce E, Cantrell V, Borvak J, Banchereau J, et al. Interferon and granulopoiesis signatures in systemic lupus erythematosus blood. J Exp Med (2003) 197:711-23. doi:10.1084/jem.20021553

28. Li Y, Lee PY, Kellner E, Paulus M, Switanek J, Xu Y, et al. Monocyte surface expression of Fcgamma receptor RI (CD64), a biomarker reflecting Type-I interferon levels in systemic lupus erythematosus. Arthritis Res Ther (2010) 12:R90. doi:10.1186/ar3017

29. Herrmann M, Voll RE, Zoller OM, Hagenhofer M, Ponner BB, Kalden JR. Impaired phagocytosis of apoptotic cell material by monocyte-derived macrophages from patients with systemic lupus erythematosus. Arthritis Rheum (1998) 41:124150. doi:10.1002/1529-0131(199807)41:7<1241::AID-ART15>3.0.CO;2-H

30. Martinez-Martinez MU, Abud-Mendoza C. Predictors of mortality in diffuse alveolar haemorrhage associated with systemic lupus erythematosus. Lupus (2011) 20:568-74. doi:10.1177/0961203310392430

31. Peyssonnaux C, Cejudo-Martin P, Doedens A, Zinkernagel AS, Johnson RS, Nizet V. Cutting edge: essential role of hypoxia inducible factor-1alpha in development of lipopolysaccharide-induced sepsis. J Immunol (2007) 178:7516-9. doi:10.4049/jimmunol.178.12.7516
32. Cramer T, Yamanishi Y, Clausen BE, Forster I, Pawlinski R, Mackman N, et al. HIF-1alpha is essential for myeloid cell-mediated inflammation. Cell (2003) 112:645-57. doi:10.1016/S0092-8674(03)00154-5

33. Ban HS, Xu X, Jang K, Kim I, Kim BK, Lee K, et al. A novel malate dehydrogenase 2 inhibitor suppresses hypoxia-inducible factor- 1 by regulating mitochondrial respiration. PLoS One (2016) 11:e0162568. doi:10.1371/ journal.pone. 0162568

34. Joseph SB, Castrillo A, Laffitte BA, Mangelsdorf DJ, Tontonoz P. Reciprocal regulation of inflammation and lipid metabolism by liver X receptors. Nat Med (2003) 9:213-9. doi:10.1038/nm820

35. Beltowski J. Liver X receptors (LXR) as therapeutic targets in dyslipidemia. Cardiovasc Ther (2008) 26:297-316. doi:10.1111/j.1755-5922.2008.00062.x

36. Ito A, Hong C, Rong X, Zhu X, Tarling EJ, Hedde PN, et al. LXRs link metabolism to inflammation through Abcal-dependent regulation of membrane composition and TLR signaling. Elife (2015) 4:e08009. doi:10.7554/eLife.08009

37. Kim SY, Yang EG. Recent advances in developing inhibitors for hypoxiainducible factor prolyl hydroxylases and their therapeutic implications. Molecules (2015) 20:20551-68. doi:10.3390/molecules201119717

38. Hong C, Tontonoz P. Liver X receptors in lipid metabolism: opportunities for drug discovery. Nat Rev Drug Discov (2014) 13:433-44. doi:10.1038/ $\operatorname{nrd} 4280$

39. Hill GS, Delahousse M, Nochy D, Remy P, Mignon F, Mery JP, et al. Predictive power of the second renal biopsy in lupus nephritis: significance of macrophages. Kidney Int (2001) 59:304-16. doi:10.1046/j.1523-1755.2001.00492.x

40. Olmes G, Buttner-Herold M, Ferrazzi F, Distel L, Amann K, Daniel C. CD163+ M2c-like macrophages predominate in renal biopsies from patients with lupus nephritis. Arthritis Res Ther (2016) 18:90. doi:10.1186/s13075-016-0989-y

41. Bergtold A, Gavhane A, D’Agati V, Madaio M, Clynes R. FcR-bearing myeloid cells are responsible for triggering murine lupus nephritis. J Immunol (2006) 177:7287-95. doi:10.4049/jimmunol.177.10.7287

42. Bethunaickan R, Berthier CC, Ramanujam M, Sahu R, Zhang W, Sun Y, et al. A unique hybrid renal mononuclear phagocyte activation phenotype in murine systemic lupus erythematosus nephritis. J Immunol (2011) 186:4994-5003. doi:10.4049/jimmunol.1003010

43. Skaggs BJ, Hahn BH, McMahon M. Accelerated atherosclerosis in patients with SLE - mechanisms and management. Nat Rev Rheumatol (2012) 8:214-23. doi:10.1038/nrrheum.2012.14

44. Moore KJ, Sheedy FJ, Fisher EA. Macrophages in atherosclerosis: a dynamic balance. Nat Rev Immunol (2013) 13:709-21. doi:10.1038/nri3520

45. Fredman G, Tabas I. Boosting inflammation resolution in atherosclerosis: the next frontier for therapy. Am J Pathol (2017) 187:1211-21. doi:10.1016/j. ajpath.2017.01.018

46. Nagata S, Hanayama R, Kawane K. Autoimmunity and the clearance of dead cells. Cell (2010) 140:619-30. doi:10.1016/j.cell.2010.02.014

47. Castrillo A, Joseph SB, Vaidya SA, Haberland M, Fogelman AM, Cheng G, et al. Crosstalk between LXR and toll-like receptor signaling mediates bacterial and viral antagonism of cholesterol metabolism. Mol Cell (2003) 12:805-16. doi:10.1016/S1097-2765(03)00384-8

48. Pascual-Garcia M, Rue L, Leon T, Julve J, Carbo JM, Matalonga J, et al. Reciprocal negative cross-talk between liver $\mathrm{X}$ receptors (LXRs) and STAT1: effects on IFN-gamma-induced inflammatory responses and LXRdependent gene expression. J Immunol (2013) 190:6520-32. doi:10.4049/ jimmunol.1201393

49. Saas P, Varin A, Perruche S, Ceroi A. Recent insights into the implications of metabolism in plasmacytoid dendritic cell innate functions: potential ways to control these functions. F1000Res (2017) 6:456. doi:10.12688/ f1000research.11332.1

Conflict of Interest Statement: The authors declare that the research was conducted in the absence of any commercial or financial relationships that could be construed as a potential conflict of interest.

Copyright (®) 2018 Han, Zhuang, Shumyak, Wu, Xie, Li, Yang and Reeves. This is an open-access article distributed under the terms of the Creative Commons Attribution License (CC BY). The use, distribution or reproduction in other forums is permitted, provided the original author(s) and the copyright owner are credited and that the original publication in this journal is cited, in accordance with accepted academic practice. No use, distribution or reproduction is permitted which does not comply with these terms. 